\title{
Job-Related Well-Being Through the Great Recession
}

\author{
Francis Green • Alan Felstead • Duncan Gallie $\cdot$ Hande Inanc
}

Published online: 18 December 2014

(C) Springer Science+Business Media Dordrecht 2014

\begin{abstract}
We study how job-related well-being (measured by Warr's 'Enthusiasm' and 'Contentment' scales) altered through the Great Recession, and how this is related to changing job quality. Using nationally representative data for Britain, we find that jobrelated well-being was stable between 2001 and 2006, but then declined between 2006 and 2012. We report relevant changes in job quality. In modelling the determinants of jobrelated well-being, we confirm several previously-studied hypotheses and present some new findings: downsizing, work re-organisation, decreased choice, and linking pay to organisational performance each reduce well-being; indicators of skills challenge in jobs have more of a positive association with Enthusiasm than with Contentment, while effort has a more negative association with Contentment than with Enthusiasm. Our estimates are largely orthogonal to the effects of personality traits and demographic controls on wellbeing. Using a standard decomposition, we find that the 2006-2012 fall in job-related wellbeing is partly accounted for by accelerations in the pace of workplace change, rising job insecurity, increased effort and changing participation.
\end{abstract}

Keywords Effort · Job insecurity · Downsizing · Performance-related pay · Organisational participation · Job-related well-being · Task discretion · Skill

F. Green (ه)

LLAKES Centre, UCL Institute of Education, 20 Bedford Way, London WC1H OAL, UK e-mail: f.green@ioe.ac.uk
A. Felstead
Cardiff University, Cardiff, UK
D. Gallie
Nuffield College, Oxford University, Oxford, UK
H. Inanc
OECD, Paris, France 
PsycINFO Classification $3600 \cdot 3650$

JEL Classification $\mathrm{J} 53 \cdot \mathrm{I} 00 \cdot \mathrm{J} 0$

\section{Introduction}

This paper is concerned with what happens to the job-related well-being of those in employment in a major recession. Periods of economic crisis and stagnation are typically seen as occasions for accelerated changes in employment and production relations. Whether through Schumpeterian creative destruction or through a shift in the balance of power, the opportunity may be taken to renew working methods, relationships and pay bargains, with consequences for both employers and their employees. Major economic downturns are known to generate falls in general well-being (as manifested in overall life satisfaction and health indicators) which extend beyond those rendered involuntarily unemployed to the broader workforce who feel less secure and to their dependants (Burchell 1994; Di Tella et al. 2003; Green 2011). The focus here, however, is on how indicators of job-related wellbeing (feelings about one's job) are changed over a recession, and on how this is related to changing job quality. To investigate this, we examine the specific instance of employees in Britain before and after the 'Great Recession' of 2008-2009.

Since job-related well-being is an end in itself, studying it needs no additional motivation. Nevertheless, there is evidence that job-related well-being is associated with productivity, absenteeism and labour turnover (e.g. Böckerman and Ilmakunnas 2012; De Neve et al. 2013; Warr 2007; Zelenski et al. 2008) —even if much remains to be done to determine the magnitude of the causal effects. In recent years well-being-including in the domain of work-has been assigned a place in the 'beyond GDP' agenda (Stiglitz et al. 2009). A better understanding of various dimensions of well-being at an aggregate level are relevant to this agenda, and should also prove helpful in the analysis of labour markets. Britain's experience of the Great Recession was fairly typical among many other countries, with falling GDP and rising unemployment. Between 2008(Q1) and 2009(Q3) the fall in GDP $(6.03 \%)$ was somewhat larger than the average among OECD countries $(4.15 \%)$ (OECD 2010). The fall in employment over the same period being (at $1.92 \%$ ) a little lower than for the OECD as a whole $(2.30 \%)$, Britain's aggregate productivity fell more than the average. Nevertheless, it is plausible to suppose that the findings for Britain might generalise to many other developed countries.

This paper contributes in four ways. First, we show what has been happening to the economy-wide average level of job-related well-being in Britain. Since 2001 we have collected three cross-sections of large-scale nationally-representative data, with which we can document the trend in two dimensions of job-related well-being, using indicators devised by Warr (1990a; 2007). Our second contribution is to decompose the differences in job-related well-being over time, showing the proportions of these differences that can be modelled or 'explained' by variation in observed measures of job quality, and how much is left unexplained. Our third new contribution arises through this modelling of job-related well-being. Economics, psychology and sociology all provide theory as to how job characteristics are expected to be related to well-being. We fit models derived from core theories, concerning the effects of effort (work intensity and duration), participation, skills challenge and insecurity. In so doing we provide tests of hypotheses concerning the nonlinearity of effort's effect on well-being, the effects of performance-related pay, the effects of workplace change, and some variations in effects between different dimensions of well- 
being. Finally, this modelling also incorporates several better-established findings in the literature on the study of work. Most of these findings have been established in relatively small-scale, focussed, studies of particular work settings or occupations. Our fourth contribution is to examine whether these findings can be confirmed in the context of a nationally-representative survey, covering a wide variety of workers and jobs.

The paper proceeds, first, by clarifying the concept of job-related well-being, outlining the core theories to be incorporated into our model, and noting the existing evidence. The following section describes our data and all the relevant indicators, and this leads into our presentation of a picture of changing well-being and of changing job quality in Britain, comparing before and after the onset of the Great Recession. Model findings are then presented, culminating in the decomposition analysis.

\subsection{Theory and Prior Evidence Linking Job Characteristics and Job-Related Well-Being}

Psychological research has suggested that there are two substantive, if not exhaustive, orthogonal dimensions to the structure of feelings, namely 'arousal' and 'pleasure' (Warr 1990a; 2007). Within the 'arousal'/'pleasure' plane there are two correlated dimensions, namely Depression-Enthusiasm and Anxiety-Contentment. This structure for subjective well-being has the advantage that it can apply to feelings arising from both work and nonwork settings. In this paper we use a shortened nomenclature, namely 'Enthusiasm' and 'Contentment'. Enthusiasm is positively correlated with the arousal and pleasure axes. Contentment, by contrast, is correlated positively with the 'pleasure' dimension and negatively with the 'arousal' dimension. Applied to the job, employees with high Enthusiasm - with high pleasure and stimulation from their work-are said to have feelings central to the model of "thriving" (Spreitzer et al. 2005), while conversely those with low Enthusiasm express feelings of depression, who take no pleasure from their work and are passive. Those with high Contentment find their jobs acceptable but are said to have a "resigned satisfaction", while conversely those with low Contentment express feelings of anxiety, being both aroused by and experiencing displeasure from their work (Grebner et al. 2005; Warr 2007: 22). These two dimensions have been found to affect behaviour, including quitting and absenteeism (Green 2010; Warr 2007: 427-434). As Warr notes (2007: 19-60), both dimensions are positively related to mental health indicators (but in subtle ways involving varying thought processes) and to other constructs such as organisational commitment and job satisfaction.

Warr (1990a) has examined and validated instruments (to be described below) that tap these dimensions. Other concepts of job-related well-being are also sometimes available for analysis. Not least, job satisfaction might be considered as an indicator of well-being along the 'pleasure' dimension, even though its interpretation depends a great deal on workers' expectations of potential alternative work settings (Brown et al. 2012). In recent years other researchers have developed subjective well-being scales which incorporate cognitive evaluative dimensions alongside affective-emotional aspects (for example, Tennant et al. 2007). We chose Warr's scales of Enthusiasm and Contentment when planning the 2001 Skills Survey, given that these were available in the public domain, and had been well validated and already widely cited at the time (Mullarkey et al. 1999). Continuity then became essential for the identification of changes over time in successive, nationally representative, samples. 
We draw on core literatures to formulate hypotheses about the links between job quality and subjective well-being. One can think of the determination of each dimension $(i)$ of jobrelated well-being $J W B_{i}$ as:

$$
J W B_{i}=f_{i}\left(J Q_{j}, X_{k}\right)
$$

In this equation $J Q_{j}$ is a vector of job quality, defined as in the literature as that subset of job characteristics which meet people's needs from work (Green 2006; Kalleberg 2011; Körner et al. 2011). $X_{k}$ is a vector of personal and environmental characteristics which might directly affect subjective well-being or moderate the relationship between job quality and the expression of subjective well-being. The psychology, sociology and economics literatures point to several sets of determinants as important determinants of wellbeing, which may have been significantly changed through the recession: effort, participation, skills challenge, insecurity and workplace change. ${ }^{1}$ A major recession directly affects insecurity and the pace of workplace change; through the pressures of heightened competition, rising unemployment and the shifting balance of power in the employerworker bargain, recession may also affect worker effort and moderate the long-term evolutions of skills utilisation and forms of participation (Green 2009; van Wanrooy et al. 2013). We discuss each of these sets of determinants in turn below. This simple framework enables us to model the findings of previous studies, and to highlight some hypotheses not previously tested with nationally representative data. Considering these hypotheses together helps frame our expectation about how recession may have affected job-related wellbeing.

\subsubsection{Effort}

Effort is comprised of both work intensity and work duration. Sometimes work intensity is termed as "intensive work effort", and duration as "extensive work effort" (Green 2001, 2006). The former is complex, entailing a mix of physical, mental and emotional demands at work, and involves added measurement issues due to its lack of a standard metric. ${ }^{2}$

Economics has evolved the view that intensive and extensive work effort are each a disutility at the margin, a 'bad', something that has to be experienced in order to earn a wage (Spencer 2009), and in this it parallels modern psychology (Warr 2007; Wichert 2002). Both economics (with its fundamental assumption of increasing marginal disutility of work) and psychology take the theoretical relationship of effort with well-being to be non-linear, with increasing negative marginal effects. These propositions underpin labour supply theory in economics, and as such are indirectly attested by the voluminous empirical literature on labour supply (e.g. Ashenfelter et al. 2010; Hamermesh 1993). Direct psychological studies using measures of work intensity have varied findings: some report that high effort is associated with lower levels of job satisfaction and/or Contentment, while others find a very low correlation between job satisfaction and work intensity (Warr 2007: 165-170; Wood and de Menezes 2011). Cottini and Lucifora (2013) report

\footnotetext{
1 While our included sets of determinants are broad-ranging, another set of characteristics which affect well-being concern work-life balance, which might also have changed somewhat through the recession (Beham and Drobnič 2011); unfortunately we cannot include this in our study owing to lack of data.

2 In the psychological literature the phrase "job demands" is, in some cases, used to mean work intensity in the sense of this paper (e.g. Hakanen et al., 2008), but more commonly job demands is used more broadly to embrace both work intensity and role conflict (Warr, 2007), even though six out of the seven items used to measure job demands by Karasek (1979) focus on work intensity.
} 
that higher work intensity is a source of increased mental health problems. Since the stimulation of work affects the arousal dimension, it is also expected that work intensity's effect on Enthusiasm is less negative than its effect on Contentment (Warr 1990b). However, we are not aware of any direct evidence in favour or against this expectation. These hypotheses surrounding work effort may be summarised as:

H1 Effort has an overall negative association with well-being.

H2 The magnitude of the marginal negative effect is greater at higher effort levels.

H3 The marginal effect of work intensity on well-being is less negative in respect of Enthusiasm than in respect of Contentment.

\subsubsection{Participation}

In several complementary literatures from psychology, management, sociology and economics, participation is assumed to have usually beneficial effects on job-related wellbeing (e.g. Böckerman et al. 2012; Kalleberg et al. 2009; Karasek 1979). Yet participation is a broad concept and it is useful to distinguish between two types-decision-making participation (at various levels) and financial participation in outcomes—and also between levels of participation (that is, individual, work team and wider organisation). 'Task discretion' (over various aspects of the tasks to be performed) refers to decision-making participation at the level of workers' own jobs. From the economic perspective, the task discretion afforded to individual workers will depend on workers' preferences (organisational commitment) and the monitoring structure (Green 2008), while from the sociological perspective workers' preferences are also determined by the level of trust (Fox 1980). There is much evidence that task discretion enhances well-being (e.g. Cottini and Lucifora 2013). There is also evidence that well-being is enhanced where the teams through which work is organised are granted some influence over tasks, choice of team members and team leader (Böckerman et al. 2012; Gallie et al. 2012). According to the 'demand-control' model, the impact of task discretion on well-being is greater where work intensity is high, because higher task discretion allows workers to partially counter the stressful effects of high-intensity work (Karasek 1979; Karasek and Theorell 1990). From the management theorists' perspective, task discretion is just one element in the model of 'high involvement management (HIM)' which is advanced as delivering higher organisational effectiveness (Wood and de Menezes 2011). Another element in the HIM model, also stressed within the sociological literature, is participation in decision-making about the organisation. Indicators typically cover both upward and downward information flows, including suggestion schemes, consultative meetings and the use of quality circles. Involvement through representative consultation, through recognised trade unions, is also included here. These types of organisational involvement are also found to be beneficial for well-being. However, the size of the effect has been found to be less than for task discretion (Gallie 2013), and the recent evidence for an interaction between organisational involvement and work effort on health is equivocal (Eller et al. 2009).

These effects apply to both dimensions of well-being, with no expectation of having stronger effects for one or other. Thus we have further hypotheses:

H4 Decision-making participation in terms of task discretion is positively related to wellbeing. 
H5 The effect of decision-making participation in terms of task discretion on well-being is greater at high levels of work intensity.

H6 Well-being is also enhanced by organisational participation.

The anticipated effects of financial participation on well-being are, by contrast, ambivalent. Financial participation refers to the presence of economic incentives through schemes that link rewards with performance. On one hand, the uncertainty of performance outcomes introduces an element of risk which, except for risk lovers, could be expected to lower well-being (similar to the stressor effects of job insecurity, discussed below). The uncertainty may be greater for pay linked to organisational rather than individual performance. Yet it is also hypothesised that individual piece rates may induce overworking in some jobs and hence greater physical risk-taking (Bender et al. 2012; Roy 1952). There is some evidence suggesting that performance pay raises injury rates (e.g. Bender et al. 2012; Saha et al. 2004) while Freeman and Kleiner (2005) find a positive association with compensation costs. Performance pay is also found to have negative effects on general health (Bender and Theodossiou 2013; Foster and Rosenzweig 1994). On the other hand, performance pay might attract workers with a preference for risk and reward. Wood and de Menezes (2011) also hypothesised that offering collective financial participation might stimulate commitment, increasing the value that workers attach to being part of the organisation; in the event, however, they found no significant impact from either individual or group performance-related pay on Contentment. Similarly, employee discounted sharepurchase plans have been interpreted within the framework of a gift exchange of effort for reward (Bryson and Freeman 2010). The association of financial participation with both well-being domains depends on which if either of these opposing effects predominates. These arguments may be posed as competing hypotheses:

H7 Financial participation is positively related to well-being.

H8 Financial participation is negatively related to well-being.

\subsubsection{Skills Challenge}

By the umbrella concept "skills challenge" we refer here to the extent to which the work itself challenges employees to use their skills. The idea that a good degree of challenge can make people happier has a long lineage. A substantial amount of psychological evidence establishes that work which better enables people to use their abilities is associated with greater well-being (e.g. Kornhauser 1965; O’Brien 1980). In a similar vein, labour economists have reported a significant negative association between either overeducation or skill underutilisation and job satisfaction (e.g. Allen and van der Velden 2001; Green and Zhu 2010). Because of the putative link between skill use and the emotion of arousal as well as pleasure, Warr (2007) proposes in addition the hypothesis that opportunity for skill use is more strongly associated with Enthusiasm than with Contentment, though we are aware of no evidence in favour or against this proposition. A related aspect of the skill challenge is the variety encountered in a job and the need to learn new things, both of which would be expected to have the same differential effects on well-being. Finally, the extent to which jobs involve carrying out repetitive tasks might be expected to have negative effects on Enthusiasm, but less of a detrimental effect on Contentment. All these ideas may be summed up in the hypotheses:

H9 Greater use of workers' skills is associated with higher well-being. 
H10 The effect of skills challenge on Enthusiasm is stronger than its effect on Contentment.

\subsubsection{Insecurity}

The fourth set of theories we incorporate concern insecurity, which is seen as a stressor with detrimental effects on well-being, stemming from the associated loss of control (Greenhalgh and Rosenblatt 1984). The impact of insecurity has also been interpreted as contributing to a repudiation of the implicit 'psychological contract' (Mauno et al. 2005) or as part of a shift in power relations (Scott 2004). Our primary focus is on the risk of job loss, which is expected to affect both Enthusiasm and Contentment. For this there is already robust and voluminous evidence from studies of ex-ante job insecurity (e.g. Burchell 1994; Cheng and Chan 2008; Green 2011; Nolan et al. 2000; Wichert 2002) and indirectly from studies of ex-post indicators such as job loss and unemployment (e.g. Di Tella et al. 2003; Theodossiou 1998). Insecurity can also entail uncertainty over valued job features within the current job, including fears of unfair treatment or loss of job status, though for lack of data in successive waves of our data series we are unable to test whether such fears may add to an explanation for changing well-being (Gallie et al. 2013). The main hypothesis is therefore:

H11 Job insecurity is negatively related to well-being.

\subsubsection{Workplace Change}

Workplace change may have an indirect effect on well-being, through its effects on any of the above aspects of job quality. Yet change may also have a direct effect.

A direct negative impact on well-being is to be expected from the disruptions of restructuring-employment downsizing, pay cuts, new technologies and work re-organisation. For example, it is held that, for those employees who 'survive' it without losing their jobs, downsizing is a rupture in the 'psychological contract' which reduces their organisational commitment and well-being. There are a few studies to support this. Bryson et al. (2013), for example, report that changes in work organisation are associated with lower Contentment, but that this effect is ameliorated where unions with bargaining rights are consulted over the reorganisation. Datta et al. (2010) review evidence that downsizing tends to lower job satisfaction and organisational commitment. Typically, studies report greater negative direct effects on survivors of downsizing the nearer they are to being involved, and the less fair are the perceived processes (Pepper et al. 2003). A counter-argument sometimes posed, however, is that if job-related well-being is assessed relative to those made redundant, there could be a positive survivor effect among those in work during a recession-a feeling of relief that their jobs have not been lost. There may also be direct effects (positive or negative) on well-being from changing jobs.

H12 Disruptive workplace changes are negatively associated with well-being, conditional on their indirect effects via changing job characteristics.

H13 Surviving downsizing could be associated with relative relief, hence greater wellbeing. 


\subsubsection{The Expected Effect of Recession}

These hypotheses enable us to frame an expectation about the impact of economic downturns on job-related well-being. While it is well-established that downturns are detrimental for general well-being, we are concerned here with the effect on job-related wellbeing. Recessions, which are expected to be a time of accelerated restructuring and workplace change, could affect the job-related well-being of those remaining in work. In part, recessions' expected effects hinge on H12 and H13. In addition, however, other job characteristics are likely to alter during recessions. Overall, the potential effects are also uncertain. On one hand, in a recession employers' bargaining power is increased, thus enabling them to enforce a greater level of work intensity; recession and stagnation could also be expected to elevate both the fear of both job loss and anxiety about unfair treatment (Gallie et al. 2013). On the other hand labour hoarding in recessions implies lower work intensity and hours. There could also be a selection effect, with surviving workers more likely to have higher productivity than those laid off, and greater well-being.

Given the depth of the Great Recession, our prior expectation was that a rising prevalence of insecurity, restructuring and other deteriorations in job quality would lead to a reduction in job-related well-being in both dimensions. In what follows our aim is, not to test whether the Great Recession caused changes in job-related well-being, but to investigate what happened and how far factors associated with recession, such as restructuring and rising insecurity, were present and are associated with job-related well-being. Specifically, we ask: what happened to the two dimensions of job-related well-being between 2006 (before the recession) and 2012? How far was the pace of restructuring and workplace change heightened in this interval? How did core elements of job quality change between these two dates? In the light of our estimates of the association of job characteristics and of workplace change with job-related well-being, we then decompose the observed change into a part that can be 'accounted for' by accelerated workplace change and by changes in job quality, and a residual that cannot be linked to observed variables.

\subsection{Data and Indicators}

To examine these questions, together with the hypotheses derived from the core theories, we use data from the British Skills and Employment Surveys, a series of periodic nationally representative sample surveys of individuals in employment which we have collected. Sample sizes were 4,470 in 2001, 7,787 in 2006 and 3,200 in 2012; the full survey details are reported in Felstead et al. $(2002,2007)$ and, for 2012, at http://www. llakes.org/. The surveys collected responses from working adults interviewed in their own homes. Interviews lasted less than $1 \mathrm{~h}$ on average, no evidence of tiredness was observed and no interviews were abandoned The samples were drawn using random probability principles subject to stratification based on socio-economic indicators, and only one eligible respondent per address was randomly selected for interview. Weights were computed to take into account the differential probabilities of sample selection, the over-sampling of certain areas and some small response rate variations between groups (defined by sex, age and occupation); all of the analyses that follow use these weights.

We focus in our analyses only on employees, because some of the key variables under study are likely to be interpreted somewhat differently by the self-employed. We collected data on job-related well-being using Warr's scales in the 2001, 2006 and 2012 surveys. To measure the two dimensions of job-related well-being-Enthusiasm and Contentment-a series of items was introduced with the words: 'Thinking of the past few weeks, how much 
of the time has your job made you feel each of the following...?', each followed by an adjective describing a different feeling. For the Enthusiasm scale, the adjectives were 'depressed', 'gloomy', 'miserable', 'cheerful', 'enthusiastic' and 'optimistic'. For the Contentment scale the adjectives were 'tense', 'uneasy', 'worried', 'calm', 'contented' and 'relaxed'. Possible responses were 'never', 'occasionally', 'some of the time', 'much of the time', 'most of the time' and 'all of the time'. Both scales are constructed by averaging the responses, having reversed the negative items, ranged from 1 to 6 . In our samples the Cronbach's alpha statistic was 0.81 for both Enthusiasm and Contentment, suggesting that it is reasonable to regard the elements of each scale as capturing an underlying dimension.

Work duration is indicated by the number of hours usually worked per week. We derived a Work Intensity Index that includes multiple facets, constructed from the following elements: (a) the perception of required hard work; (b) the frequency of working to tight deadlines; (c) the frequency of having to work at very high speeds; (d) the frequency of experiencing difficulty to complete tasks in time; (e) the frequency of returning home from work exhausted; (f) the perception of putting in additional effort beyond requirements; (g) average task demands (derived from 40 items). ${ }^{3}$ These seven items were combined, after standardising, into a single scale, with a Cronbach's alpha statistic of 0.72 . Our findings described below are not sensitive to reasonable alternative methods of constructing this index.

We generated the Task Discretion Index from four items which assess how much personal influence people report over specific aspects of their jobs: how hard they work, deciding what tasks they are to do, how the tasks are done and the quality standards to which they work. The response options ranged from 'a great deal', 'a fair amount' to 'not much' and 'not much at all'. A summary index was constructed, by taking the average of responses of the four items. The Cronbach's alpha coefficient is 0.77 . We also include a measure of whether employees have some influence over tasks through the teams they work in. We asked whether they worked in a group, and if so how much influence the team had over the same aspects of the team's work. We generated a dummy variable indicator for 'semi-autonomous' team, equal to one if the employee worked in a team where the average amount of team influence was at least 'a fair amount', zero otherwise. Our measures of participation are then supplemented by a dummy variable indicating whether the worker has 'a great deal' of say in decisions that change the way the job is done. Organisational involvement is indicated, first, by a dummy variable for participation in quality circles. Second, we computed an indicator (range 0-8) for organisational communications via meetings with management: the sum of the number of issues (finance, investment, working practices, company products, health and safety, training plans and other matters) that can be raised in consultative meetings and a dummy for informationgiving meetings. We also included an indicator for union voice: a dummy variable for whether unions are present in the establishment and reported to have a 'fair amount' or 'a great deal' of influence over work organisation.

Financial participation is captured by three dummy variables indicating whether the respondent receives, as part of pay, a bonus linked to individual, team or organisational performance (the latter including the facility to participate in a share ownership or option scheme).

To capture skills challenge we used four indicators. Two were dummy variables covering whether the job required them to keep learning new things, and whether it never involved carrying out short, repetitive tasks. The third indicator is how much variety there

\footnotetext{
3 These indicators of the importance of tasks in jobs are described fully elsewhere, e.g. Green (2012).
} 
is in the job. The fourth indicator captures how far respondents agreed with the statement 'I have enough opportunity to use the knowledge and skills that I have'.

To capture job insecurity respondents were asked whether there was any chance of them becoming unemployed and losing their job in the next 12 months, and if so how likely this was on a five-point scale ranging from 'very unlikely' to 'very likely'. In previous studies it has been shown that expectations of job loss are well-informed (Dickerson and Green 2009; Stephens 2004).

Several measures of workplace change are also included. We ascertained whether skills used had changed, respondents had been promoted or their choice over work methods had changed since a recent reference point. ${ }^{4}$ While some will have changed employer since the reference point, among those that did not do so we ascertained whether new technology (specifically, new computerised or automated equipment) had been introduced, whether work had been reorganised, and whether there had been some downsizing (specifically, a reduction in the number of people doing the job). We would also liked to have included an indicator of wage cuts, but this was not available in the data.

\subsection{A Picture of Job-Related Well-Being and (Non-pay) Job Quality in Britain, 2001-2012}

The first question we address is whether job-related well-being has risen, fallen, or remained stable through the recession. To set this in context, we also include the 2001 picture for this description. Pooling the data from all three waves, and using a consistent base across years (employees aged 20-60, living in England, Scotland or Wales) the Enthusiasm index has a mean of 4.27 while Contentment has a mean of 3.72. Table 1 shows that there was no significant change in job-related well-being between 2001 and 2006, but that in the next 6 years well-being fell significantly in both dimensions. The change was quite substantial, amounting to around 7 and $20 \%$ of the standard deviations of Contentment and Enthusiasm respectively. Thus, while in theory the direction of change in job-related well-being for those still in employment in a recession could not be predicted, in practice the direction of change through the Great Recession was downwards.

The two indices can each be divided into sub-indices covering just the positive or just the negative items. This is of interest because other studies using these scales may focus on just the positive or the negative items. Table 1 reveals that declines in the Contentment index over 2006-2012 occur for both negative and positive items, though the negative items decline somewhat more (0.24 compared with 0.11$)$. With the Enthusiasm index only the negative items decline.

Differences can also be observed between the changes in the well-being of males and females. In the case of Contentment the index falls further for males than for females $(0.24$ compared with 0.11), while with Enthusiasm the index falls for males but not at all for females.

Having established that job-related well-being declined in the 2006-2012 period, we now examine what happened to the pace of workplace change and to our indicators of job quality. As can be seen in Table 1, there was an increase in the Work Intensity Index, especially between 2006 and 2012-a work intensification. Meanwhile working hours

\footnotetext{
${ }^{4}$ We asked respondents if they were in work 5 years prior to interview, and if so this would become their reference point for subsequent change questions. If not employed then, they were asked the same question about 4 years, then if not employed at that point, again about 3 years. This device enabled us to heighten the number of responses with qualitative information about recent workplace change.
} 
Table 1 Job-related well-being and job characteristics in 2001, 2006 and 2012

\begin{tabular}{|c|c|c|c|c|c|c|c|}
\hline Concept & Indicators & $\begin{array}{l}2001 \\
\text { mean }\end{array}$ & $\begin{array}{l}2006 \\
\text { mean }\end{array}$ & $\begin{array}{l}2012 \\
\text { mean }\end{array}$ & $\begin{array}{l}\text { Pooled } \\
\text { SD }\end{array}$ & $\begin{array}{l}\text { Change } \\
01-06\end{array}$ & $\begin{array}{l}\text { Change } \\
06-12\end{array}$ \\
\hline \multirow{10}{*}{$\begin{array}{l}\text { Job-related } \\
\text { well-being }\end{array}$} & Enthusiasm & 4.29 & 4.27 & 4.22 & 0.83 & -0.02 & $-0.06 * * *$ \\
\hline & Contentment & 3.76 & 3.75 & 3.58 & 0.89 & 0.00 & $-0.18 * * *$ \\
\hline & $\begin{array}{l}\text { Enthusiasm (positive } \\
\text { items) }\end{array}$ & 3.35 & 3.31 & 3.32 & 1.12 & -0.04 & 0.01 \\
\hline & $\begin{array}{l}\text { Contentment (positive } \\
\text { items) }\end{array}$ & 2.85 & 2.84 & 2.73 & 1.13 & -0.01 & $-0.11 * * *$ \\
\hline & $\begin{array}{l}\text { Enthusiasm (negative } \\
\text { items) }\end{array}$ & 5.23 & 5.23 & 5.12 & 0.88 & 0.00 & $-0.12 * * *$ \\
\hline & $\begin{array}{l}\text { Contentment (negative } \\
\text { items) }\end{array}$ & 4.67 & 4.67 & 4.42 & 0.95 & 0.00 & $-0.24 * * *$ \\
\hline & Enthusiasm (males) & 4.25 & 4.24 & 4.12 & 0.83 & 0.00 & $-0.12 * * *$ \\
\hline & Contentment (males) & 3.78 & 3.80 & 3.56 & 0.88 & 0.02 & $-0.24 * * *$ \\
\hline & Enthusiasm (females) & 4.34 & 4.30 & 4.32 & 0.82 & -0.03 & 0.01 \\
\hline & Contentment (females) & 3.74 & 3.71 & 3.59 & 0.89 & -0.03 & $-0.11 * * *$ \\
\hline \multirow[t]{2}{*}{ Effort } & Work Intensity Index & -0.042 & -0.015 & 0.050 & 0.634 & $0.027 * *$ & $0.065 * * *$ \\
\hline & Hours per week & 37.217 & 36.704 & 36.205 & 12.498 & $-0.513^{*}$ & $-0.499 *$ \\
\hline \multirow[t]{9}{*}{ Participation } & Task Discretion Index & 2.183 & 2.18 & 2.184 & 0.657 & -0.003 & 0.004 \\
\hline & $\begin{array}{l}\text { Semi-autonomous } \\
\text { Team }^{\text {DV }}\end{array}$ & 0.144 & 0.143 & 0.178 & 0.357 & -0.001 & $0.035 * * *$ \\
\hline & $\begin{array}{l}\text { Influence on change in } \\
\text { work method }\end{array}$ & 0.357 & 0.313 & 0.263 & 0.465 & $-0.044 * * *$ & $-0.050^{* *}$ \\
\hline & $\begin{array}{l}\text { Quality circle } \\
\text { participation }^{\mathrm{DV}}\end{array}$ & 0.370 & 0.424 & 0.394 & 0.49 & 0.054 & $-0.030^{* *}$ \\
\hline & $\begin{array}{l}\text { Organisational } \\
\text { Communications } \\
\text { Index }\end{array}$ & 3.646 & 4.217 & 4.194 & 2.833 & $0.571^{* * *}$ & -0.023 \\
\hline & Union voice ${ }^{\mathrm{DV}}$ & 0.196 & 0.194 & 0.181 & 0.394 & -0.002 & -0.013 \\
\hline & Individual $\mathrm{PRP}^{\mathrm{DV}}$ & 0.256 & 0.291 & 0.280 & 0.448 & $0.035^{* * *}$ & -0.011 \\
\hline & Team PRP ${ }^{\mathrm{DV}}$ & 0.152 & 0.159 & 0.179 & 0.367 & 0.007 & $0.020 * *$ \\
\hline & Organisation $\mathrm{PRP}^{\mathrm{DV}}$ & 0.330 & 0.307 & 0.293 & 0.463 & $-0.023^{* *}$ & -0.014 \\
\hline \multirow{9}{*}{$\begin{array}{l}\text { Skills } \\
\text { Challenge }\end{array}$} & Learning $^{\mathrm{DV}}$ & 0.811 & 0.823 & 0.823 & 0.385 & 0.012 & 0.000 \\
\hline & \multicolumn{7}{|c|}{ Variety (ref. some, little or none) } \\
\hline & 'Quite a lot' & 0.325 & 0.34 & 0.337 & 0.472 & 0.015 & -0.003 \\
\hline & 'Great deal' & 0.334 & 0.309 & 0.305 & 0.465 & $-0.025 * * *$ & -0.004 \\
\hline & Non-repetitive tasks ${ }^{\mathrm{DV}}$ & 0.244 & 0.234 & 0.199 & 0.421 & -0.010 & $-0.035 * * *$ \\
\hline & \multicolumn{7}{|c|}{ Enough opportunity for skill use? (Ref. strongly agree) } \\
\hline & Agree & 0.484 & 0.433 & 0.446 & 0.498 & $-0.051 * * *$ & 0.013 \\
\hline & Disagree & 0.146 & 0.122 & 0.100 & 0.331 & $-0.024 * * *$ & $-0.022 * * *$ \\
\hline & Strongly disagree & 0.040 & 0.045 & 0.031 & 0.197 & 0.005 & $-0.014 * * *$ \\
\hline \multirow{3}{*}{$\begin{array}{l}\text { Job } \\
\text { insecurity }\end{array}$} & \multicolumn{7}{|c|}{ Job insecurity (chance of job loss): (ref. no chance or very unlikely) } \\
\hline & Quite unlikely/evens & 0.095 & 0.116 & 0.158 & 0.323 & $0.021 * * *$ & $0.042 * * *$ \\
\hline & $\begin{array}{l}\text { Quite likely/very } \\
\text { likely }\end{array}$ & 0.062 & 0.058 & 0.066 & 0.239 & -0.004 & 0.008 \\
\hline
\end{tabular}


Table 1 continued

\begin{tabular}{|c|c|c|c|c|c|c|c|}
\hline Concept & Indicators & $\begin{array}{l}2001 \\
\text { mean }\end{array}$ & $\begin{array}{l}2006 \\
\text { mean }\end{array}$ & $\begin{array}{l}2012 \\
\text { mean }\end{array}$ & $\begin{array}{l}\text { Pooled } \\
\text { SD }\end{array}$ & $\begin{array}{l}\text { Change } \\
01-06\end{array}$ & $\begin{array}{l}\text { Change } \\
06-12\end{array}$ \\
\hline \multirow{8}{*}{$\begin{array}{l}\text { Workplace } \\
\text { change }\end{array}$} & Skill increase $\mathrm{eV}^{\mathrm{DV}}$ & 0.599 & 0.576 & 0.539 & 0.494 & $-0.023 * *$ & $-0.037 * * *$ \\
\hline & Promoted $^{\mathrm{DV}+}$ & - & 0.379 & 0.354 & 0.483 & - & $-0.025^{* *}$ \\
\hline & $\begin{array}{l}\text { Increased choice over } \\
\text { way job done }\end{array}$ & - & 0.414 & 0.363 & 0.490 & - & $-0.051 * * *$ \\
\hline & $\begin{array}{l}\text { Decreased choice over } \\
\text { way job done } \mathrm{DV}^{\mathrm{D}}\end{array}$ & - & 0.117 & 0.153 & 0.334 & - & $0.036 * * *$ \\
\hline & Changed employer ${ }^{\mathrm{DV}+}$ & - & 0.430 & 0.393 & 0.473 & - & $-0.037 * * *$ \\
\hline & $\begin{array}{l}\text { Introduction of new } \\
\text { technology }\end{array}$ & 0.616 & 0.632 & 0.579 & 0.487 & 0.016 & $-0.053 * * *$ \\
\hline & $\begin{array}{l}\text { Change in work } \\
\text { organisation }^{\mathrm{DV}++}\end{array}$ & 0.489 & 0.535 & 0.553 & 0.499 & $0.046^{* * *}$ & 0.018 \\
\hline & Downsizing $^{\text {DV }++}$ & 0.286 & 0.300 & 0.408 & 0.466 & 0.014 & $0.108 * * *$ \\
\hline
\end{tabular}

Note

(i) The base is all employees Aged 20-60

(ii) DV: 0-1 dummy variable. All variables are defined in theData and Indicators section of the text

(iii) PRP: performance-related pay

(iv) + Applies to those in employment at a past reference point; ++ applies to those who remained in the same job since the reference point. (The reference point is 5 yrs previously or, if not in employment then, 4 years previously or, if not in employment then, 3 years previously)

(v) Changes significantly different from zero at levels: *** $p<0.01$; ** $p<0.05$; $p<0.1$

came down by a small amount from 2001. Individuals' task discretion remained largely stable overall through the decade. Starting in 2006 there was an increase in the prevalence of semi-autonomous teamworking (from 14 to $18 \%$ ), coupled by a small rise in the prevalence of team-based performance-related pay (16-18\%). Communication between management and workers rose between 2001 and 2006 but thereafter stabilised. After 2006, the use of quality circles declined by a small amount, and there was also a more substantial reduction in the share reporting influence on changes in work methods (from 31 to $26 \%$ ), while union voice and non-team forms of performance-related pay were unchanged.

Skills challenges also went through small changes between 2006 and 2012, the most notable being a rise in repetitiveness (a fall from 23 to $20 \%$ in the prevalence of jobs which never entailed repetitive tasks), and a rise in the availability of opportunities for skill use.

There has been a rise in perceptions of the probability of job loss which accelerated after 2006: whereas in $200683 \%$ of employees felt that there was no chance of losing their job, or it was very unlikely, in 2012 the figure was down to $78 \%$. Gallie et al. (2013) show that this rise was complemented by a rise between 2000 and 2012 in fears of unfair treatment in the workplace.

As the table shows, rising insecurity after 2006 is also accompanied by alterations in the pace of workplace change. Most notably, the proportion of employees reporting that there had been some downsizing in their job rose from $30 \%$ in 2006 to $41 \%$ in 2012 . There were also falls in the prevalence of skill rises (58-54\%), promotion (38-35\%), workplaces with increasing job choice (41-36 \%), job mobility to another employer (43-39\%), 
and the introduction of new technology (63-58\%). These are the unsurprising accoutrements of the Great Recession in Britain.

The relevance of these job characteristics and the altered pace of change for our understanding of the changes in well-being depends on their associations with well-being, as implied by the core theories outlined above. We now therefore turn to an empirical model of these associations.

\subsection{The Determinants of Well-Being}

Table 2 presents our baseline model implied by core theories. We use the pooled nationally representative data for 2006 and 2012, in order to focus on the period in which well-being fell and because this enables us to use the full range of explanatory variables. This restriction allows us to expand the base to all employees aged 20-65. Males and females are treated separately, since different domestic circumstances (including labour market participation), preferences or opportunities may condition the effects of job quality indicators in distinct ways according to gender; also, as we have seen, their experiences differed through the recession. We use the Seemingly Unrelated Regression estimator to allow for potential correlation of the residuals in the regressions for the two well-being dimensions.

The findings confirm previous studies showing the negative association of work intensity with well-being (H1). Concerning the non-linearity hypothesis $(\mathrm{H} 2)$ the evidence is mixed. There is a negative coefficient on the square of work intensity in all four cases, but this is significant (at $1 \%$ ) only in the case of females' Contentment index. Another new finding is that the estimates support the hypothesis (H3) that work intensity impinges more on Contentment than on Enthusiasm. Evaluated at its mean (zero) the standardised effect of work intensity for females is -0.55 on Contentment and -0.25 on Enthusiasm; for males, the equivalents are -0.39 and -0.27 . These differences are each significant at $1 \%$.

As regards work hours the relationship with Enthusiasm is U-shaped, supporting H1 only up to a point and $\mathrm{H} 2$ not at all: the working week at which Enthusiasm is at a minimum is estimated to be $40 \mathrm{~h}$ for men, $53 \mathrm{~h}$ for women. This result is similar to previous findings in the literature which have found somewhat high levels of job satisfaction among those working very long hours (Benz 2005): this association is interpretable as reflecting the endogenous determination of work hours, in that some of those work long hours are choosing to do so because they enjoy the work.

The findings also confirm a substantive positive effect of individual task discretion on the two dimensions of well-being (H4). Moreover, the interaction with work intensity is positive and significant in three cases, consistent with previous evidence concerning hypothesis $\mathrm{H} 5$ that the detrimental effects of work intensity are moderated by higher levels of task discretion.

Indicators of organisational participation are also positively associated with well-being (H6). The strongest is 'influence on change in work method', which is significant for both dimensions and sexes; as an example, for females having 'a great deal' of say in organisational decisions that change the way work is done and has an effect on Enthusiasm of 0.26 (31\% of its standard deviation). Semi-autonomous team-working (with high levels of team influence over tasks) has lower coefficients, yet these are significant in 3 out of 4 cases. Quality circle participation is associated with greater Enthusiasm for males, while the Organisational Communications indicator is linked with Enthusiasm for both sexes. Union voice is beneficial in raising Contentment for males. 
Table 2 The association of job quality with job-related well-being

\begin{tabular}{|c|c|c|c|c|}
\hline & \multicolumn{2}{|l|}{ Males } & \multicolumn{2}{|l|}{ Females } \\
\hline & $\begin{array}{l}\text { (1) } \\
\text { Enthusiasm }\end{array}$ & $\begin{array}{l}\text { (2) } \\
\text { Contentment }\end{array}$ & $\begin{array}{l}(3) \\
\text { Enthusiasm }\end{array}$ & $\begin{array}{l}\text { (4) } \\
\text { Contentment }\end{array}$ \\
\hline Work intensity & $\begin{array}{l}-0.348 * * * \\
(0.0679)\end{array}$ & $\begin{array}{l}-0.542^{* * * *} \\
(0.0752)\end{array}$ & $\begin{array}{l}-0.329 * * * \\
(0.0628)\end{array}$ & $\begin{array}{l}-0.763 * * * \\
(0.0669)\end{array}$ \\
\hline Work Intensity squared & $\begin{array}{l}-0.0351 \\
(0.0252)\end{array}$ & $\begin{array}{l}-0.0307 \\
(0.0279)\end{array}$ & $\begin{array}{l}-0.0381 \\
(0.0236)\end{array}$ & $\begin{array}{l}-0.0742 * * * \\
(0.0251)\end{array}$ \\
\hline Hours per week & $\begin{array}{l}-0.0137 * * * \\
(0.00439)\end{array}$ & $\begin{array}{l}-0.00726 \\
(0.00487)\end{array}$ & $\begin{array}{l}-0.0203 * * * \\
(0.00359)\end{array}$ & $\begin{array}{l}-0.0112 * * * \\
(0.00382)\end{array}$ \\
\hline Hours squared & $\begin{array}{l}0.000169 * * * \\
(5.09 \mathrm{e}-05)\end{array}$ & $\begin{array}{l}6.10 \mathrm{e}-05 \\
(5.64 \mathrm{e}-05)\end{array}$ & $\begin{array}{l}0.000191 * * * \\
(5.41 \mathrm{e}-05)\end{array}$ & $\begin{array}{l}-1.61 \mathrm{e}-05 \\
(5.77 \mathrm{e}-05)\end{array}$ \\
\hline Task discretion & $\begin{array}{l}0.0995 * * * \\
(0.0209)\end{array}$ & $\begin{array}{l}0.105 * * * \\
(0.0232)\end{array}$ & $\begin{array}{l}0.106 * * * \\
(0.0192)\end{array}$ & $\begin{array}{l}0.101 * * * \\
(0.0204)\end{array}$ \\
\hline Work Intensity times task discretion & $\begin{array}{l}0.110 * * * \\
(0.0289)\end{array}$ & $\begin{array}{l}0.0402 \\
(0.0321)\end{array}$ & $\begin{array}{l}0.0941 * * * \\
(0.0271)\end{array}$ & $\begin{array}{l}0.131 * * * \\
(0.0289)\end{array}$ \\
\hline Semi-autonomous team & $\begin{array}{l}0.0806^{* *} \\
(0.0330)\end{array}$ & $\begin{array}{l}0.103 * * * \\
(0.0366)\end{array}$ & $\begin{array}{l}0.0140 \\
(0.0330)\end{array}$ & $\begin{array}{l}0.0981 * * * \\
(0.0351)\end{array}$ \\
\hline Influence on change in work method & $\begin{array}{l}0.266 * * * \\
(0.0278)\end{array}$ & $\begin{array}{l}0.240 * * * \\
(0.0308)\end{array}$ & $\begin{array}{l}0.257 * * * \\
(0.0268)\end{array}$ & $\begin{array}{l}0.258 * * * \\
(0.0285)\end{array}$ \\
\hline Quality circle participation & $\begin{array}{l}0.0445^{*} \\
(0.0261)\end{array}$ & $\begin{array}{l}0.0258 \\
(0.0289)\end{array}$ & $\begin{array}{l}0.0184 \\
(0.0254)\end{array}$ & $\begin{array}{l}-0.0104 \\
(0.0271)\end{array}$ \\
\hline Organisational communications & $\begin{array}{l}0.0177 * * * \\
(0.00469)\end{array}$ & $\begin{array}{l}0.00750 \\
(0.00520)\end{array}$ & $\begin{array}{l}0.0194 * * * \\
(0.00479)\end{array}$ & $\begin{array}{l}0.00538 \\
(0.00510)\end{array}$ \\
\hline Union voice & $\begin{array}{l}0.0129 \\
(0.0315)\end{array}$ & $\begin{array}{l}0.0877 * * \\
(0.0349)\end{array}$ & $\begin{array}{l}-0.00708 \\
(0.0288)\end{array}$ & $\begin{array}{l}-0.00662 \\
(0.0307)\end{array}$ \\
\hline Individual PRP & $\begin{array}{l}-0.0226 \\
(0.0300)\end{array}$ & $\begin{array}{l}-0.0215 \\
(0.0333)\end{array}$ & $\begin{array}{l}-0.0112 \\
(0.0330)\end{array}$ & $\begin{array}{l}0.0233 \\
(0.0352)\end{array}$ \\
\hline Team PRP & $\begin{array}{l}0.0313 \\
(0.0359)\end{array}$ & $\begin{array}{l}0.0423 \\
(0.0397)\end{array}$ & $\begin{array}{l}-0.0507 \\
(0.0424)\end{array}$ & $\begin{array}{l}-0.0264 \\
(0.0452)\end{array}$ \\
\hline Organisation PRP & $\begin{array}{l}-0.000112 \\
(0.0302)\end{array}$ & $\begin{array}{l}-0.0663^{* *} \\
(0.0335)\end{array}$ & $\begin{array}{l}-0.0405 \\
(0.0323)\end{array}$ & $\begin{array}{l}-0.00290 \\
(0.0344)\end{array}$ \\
\hline Learning & $\begin{array}{l}0.0392 \\
(0.0352)\end{array}$ & $\begin{array}{l}-0.114^{* * * *} \\
(0.0390)\end{array}$ & $\begin{array}{l}0.0701 * * \\
(0.0337)\end{array}$ & $\begin{array}{l}-0.0181 \\
(0.0359)\end{array}$ \\
\hline \multicolumn{5}{|l|}{ Variety (ref. some, little or none) } \\
\hline 'Quite a lot' & $\begin{array}{l}0.138 * * * \\
(0.0316)\end{array}$ & $\begin{array}{l}0.0482 \\
(0.0350)\end{array}$ & $\begin{array}{l}0.234 * * * \\
(0.0296)\end{array}$ & $\begin{array}{l}0.128 * * * \\
(0.0316)\end{array}$ \\
\hline 'Great deal' & $\begin{array}{l}0.347 * * * \\
(0.0344)\end{array}$ & $\begin{array}{l}0.200 * * * \\
(0.0381)\end{array}$ & $\begin{array}{l}0.372 * * * \\
(0.0345)\end{array}$ & $\begin{array}{l}0.151 * * * \\
(0.0367)\end{array}$ \\
\hline Non-repetitive tasks & $\begin{array}{l}0.0576 * * \\
(0.0286)\end{array}$ & $\begin{array}{l}-0.0907 * * * \\
(0.0317)\end{array}$ & $\begin{array}{l}-0.0420 \\
(0.0295)\end{array}$ & $\begin{array}{l}-0.0832^{* * * *} \\
(0.0315)\end{array}$ \\
\hline \multicolumn{5}{|c|}{ Enough opportunity for skill use? (Ref. Strongly agree) } \\
\hline Agree & $\begin{array}{l}-0.123 * * * \\
(0.0271)\end{array}$ & $\begin{array}{l}-0.138^{* * *} \\
(0.0301)\end{array}$ & $\begin{array}{l}-0.115^{* * *} \\
(0.0262)\end{array}$ & $\begin{array}{l}-0.0763 * * * \\
(0.0280)\end{array}$ \\
\hline
\end{tabular}


Table 2 continued

\begin{tabular}{|c|c|c|c|c|}
\hline & \multicolumn{2}{|l|}{ Males } & \multicolumn{2}{|l|}{ Females } \\
\hline & $\begin{array}{l}\text { (1) } \\
\text { Enthusiasm }\end{array}$ & $\begin{array}{l}\text { (2) } \\
\text { Contentment }\end{array}$ & $\begin{array}{l}\text { (3) } \\
\text { Enthusiasm }\end{array}$ & $\begin{array}{l}\text { (4) } \\
\text { Contentment }\end{array}$ \\
\hline Disagree & $\begin{array}{l}-0.254 * * * \\
(0.0424)\end{array}$ & $\begin{array}{l}-0.277 * * * \\
(0.0470)\end{array}$ & $\begin{array}{l}-0.439 * * * \\
(0.0400)\end{array}$ & $\begin{array}{l}-0.331 * * * \\
(0.0426)\end{array}$ \\
\hline Strongly disagree & $\begin{array}{l}-0.396 * * * \\
(0.0664)\end{array}$ & $\begin{array}{l}-0.290 * * * \\
(0.0735)\end{array}$ & $\begin{array}{l}-0.382 * * * \\
(0.0628)\end{array}$ & $\begin{array}{l}-0.231 * * * \\
(0.0669)\end{array}$ \\
\hline \multicolumn{5}{|c|}{ Job insecurity (chance of job loss): (ref. no chance or very unlikely) } \\
\hline Quite unlikely/evens & $\begin{array}{l}-0.204 * * * \\
(0.0335)\end{array}$ & $\begin{array}{l}-0.317 * * * \\
(0.0371)\end{array}$ & $\begin{array}{l}-0.0851^{* *} \\
(0.0381)\end{array}$ & $\begin{array}{l}-0.203 * * * \\
(0.0406)\end{array}$ \\
\hline Quite likely/very likely & $\begin{array}{l}-0.418 * * * \\
(0.0493)\end{array}$ & $\begin{array}{l}-0.289 * * * \\
(0.0547)\end{array}$ & $\begin{array}{l}-0.348 * * * \\
(0.0498)\end{array}$ & $\begin{array}{l}-0.313 * * * \\
(0.0530)\end{array}$ \\
\hline Number of observations & 3,853 & 3,853 & 4,285 & 4,285 \\
\hline $\mathrm{R}^{2}$ & 0.198 & 0.151 & 0.184 & 0.204 \\
\hline$\chi^{2}$ (independence of error terms) & 1,549 & & 1,646 & \\
\hline
\end{tabular}

Note

(i) SURE estimates are presented, with standard errors in parentheses, ${ }^{* * *} p<0.01$; $* * p<0.05$; ${ }^{*} p<0.1$

(ii) Based on pooled data from 2006 and 2012 employees aged 20-65

(iii) PRP: performance-related pay

Unlike earlier studies which report negative effects of individual-based financial participation, we find that receipt of individual or team-based pay is found to be insignificant. Financial participation through organisation-level performance schemes, however, is associated with significantly lower Contentment for males, weakly supporting H8 rather than $\mathrm{H} 7$.

The extent to which jobs are challenging is important in several ways. The estimates are consistent with previous studies, in that they show strong positive associations between the opportunity for skill use and well-being, and between job variety and well-being (H9). To illustrate how strong this effect is, for males the difference between a job with 'a great deal' of variety and one with 'some', 'little' or 'none', is 0.35 on the Enthusiasm scale, that is, $42 \%$ of its standard deviation. In addition, Warr's hypothesis (H10) is confirmed for both these variables, in that the estimated link with Enthusiasm is greater than the link with Contentment. The coefficients differ significantly: thus, for 'Great Deal' of variety $p=0.00$ for both sexes; for 'Strongly disagree' about enough opportunity for skill use, $p=0.00$ for females, $p=0.08$ for males.

In respect of the requirement to learn new things ('Learning'), the estimates show the expected positive association with Enthusiasm (significant for females), but for males the association with Contentment is significantly negative. Avoidance of repetitive tasks in a job is associated with greater Enthusiasm for males and, for both sexes, lower Contentment. Thus, with both these indicators, H10 may need amendment to a stronger version: the effect of skills challenge on Contentment is not only less than its positive effect on Enthusiasm, it may become negative.

Finally, as predicted job insecurity is associated with lower well-being in both dimensions (H11). This effect is large: for example, those females who think that they are 'quite likely' or 'very likely' to be losing their jobs in the coming year have a Contentment level of 0.31 ( $35 \%$ of SD) less than the reference category of secure employees. 


\subsection{A Robustness Issue: Controlling for Personality}

Table 2 shows that, taken together, the job characteristics account for between 15 and $20 \%$ of the variation in our measures of job-related well-being. Since these are crosssections, however, the estimates do not establish causation. For the usual reasons, many of the job characteristics could be argued to be partially affected by other variables which also affect well-being, of which a prime candidate is personality; there could also be reverse causation. Moreover, it could be that the selection of individuals into employment is related to their well-being, which would also make for potential bias. Nevertheless, one could have greater confidence that the estimates are worth taking seriously as showing consistency with theory where it is possible to control for personality and other relevant personal characteristics. We therefore investigated whether the addition of such controls substantially altered the pattern of findings just described. To do this, our analysis was confined to the 2012 data, which contained indicators of the 'Big Five' personality traitsExtraversion, Agreeableness, Conscientiousness, Emotional Stability and Openness. We included the scales derived from the short form version of these scales, designed and validated for use where interview time was scarce in large-scale surveys (Gosling et al. 2003; Muck et al. 2007).

The full results of this exercise are given in an Appendix, available on request to the first author. As expected, the introduction of the personality variables substantially increases the amount of well-being variation that is accounted for, for females reaching $37 \%$ for Enthusiasm and $30 \%$ for Contentment. Emotional Stability is especially strongly associated with both dimensions of well-being. The key observation, however, is that the estimated effects of the job quality variables do not greatly differ from those using the same specifications used in Table 2. The same observation holds for the further inclusion of demographic controls, which include age, ethnicity, education level, childhood financial security and parental interest in their school progress. Thus, despite the power of the personality variables to influence well-being, their effects and those of other controls appear to be largely orthogonal to the job quality variables of interest.

\subsection{Extension: Workplace Change and Well-Being}

Table 3 extends the basic model of well-being to incorporate workplace change. In addition to the job quality variables entered into Table 2, we introduced dummy variables for changes in respondents' jobs, whether the respondent changed employer, and if not whether he/she experienced the various workplace changes noted in Table 1. These additions are subject to the same issue of endogeneity discussed above; in particular, individuals who in their past employment had a higher well-being (which could persist into the present) might be less likely to change jobs. We therefore look only for associations, not proof of causation.

The table shows no significant associations with rising skills requirements, but promotion is associated with greater Enthusiasm for males, and lower Contentment for females. Decreased choice has detrimental effects for both dimensions for both sexes, while increased choice is beneficial for the Enthusiasm of females. Having changed employer is associated with lower Contentment. Among workplace changes, work reorganisation and (strongly) downsizing each have significant negative associations with well-being for both dimensions for both sexes. Males who report downsizing, for example, have an Enthusiasm index that is 0.14 (17\% of SD) lower than that of others where there is no downsizing. Since these models also contain, as controls, the same variables that were 
Table 3 The association of workplace changes with job-related well-being

\begin{tabular}{|c|c|c|c|c|}
\hline \multirow[t]{2}{*}{ Variables } & \multicolumn{2}{|l|}{ Males } & \multicolumn{2}{|l|}{ Females } \\
\hline & $\begin{array}{l}\text { (1) } \\
\text { Enthusiasm }\end{array}$ & $\begin{array}{l}\text { (2) } \\
\text { Contentment }\end{array}$ & $\begin{array}{l}\text { (3) } \\
\text { Enthusiasm }\end{array}$ & $\begin{array}{l}\text { (4) } \\
\text { Contentment }\end{array}$ \\
\hline Skill increase & $\begin{array}{l}0.0391 \\
(0.0268)\end{array}$ & $\begin{array}{l}0.00562 \\
(0.0296)\end{array}$ & $\begin{array}{l}0.00437 \\
(0.0273)\end{array}$ & $\begin{array}{l}-0.0413 \\
(0.0293)\end{array}$ \\
\hline Promotion & $\begin{array}{l}0.0727 * * * \\
(0.0272)\end{array}$ & $\begin{array}{l}-0.0282 \\
(0.0300)\end{array}$ & $\begin{array}{l}-0.0292 \\
(0.0268)\end{array}$ & $\begin{array}{l}-0.0738 * * \\
(0.0288)\end{array}$ \\
\hline Increased choice & $\begin{array}{l}-0.00232 \\
(0.0291)\end{array}$ & $\begin{array}{l}0.0397 \\
(0.0322)\end{array}$ & $\begin{array}{l}0.0771 * * * \\
(0.0286)\end{array}$ & $\begin{array}{l}0.0402 \\
(0.0307)\end{array}$ \\
\hline Decreased choice & $\begin{array}{l}-0.136 * * * \\
(0.0400)\end{array}$ & $\begin{array}{l}-0.170 * * * \\
(0.0442)\end{array}$ & $\begin{array}{l}-0.176 * * * \\
(0.0403)\end{array}$ & $\begin{array}{l}-0.171 * * * \\
(0.0432)\end{array}$ \\
\hline Changed employer & $\begin{array}{l}-0.0371 \\
(0.0392)\end{array}$ & $\begin{array}{l}-0.118 * * * \\
(0.0433)\end{array}$ & $\begin{array}{l}0.0280 \\
(0.0376)\end{array}$ & $\begin{array}{l}-0.103 * * \\
(0.0403)\end{array}$ \\
\hline Introduction of new technology & $\begin{array}{l}-0.0476 \\
(0.0354)\end{array}$ & $\begin{array}{l}-0.0708^{*} \\
(0.0391)\end{array}$ & $\begin{array}{l}0.0481 \\
(0.0341)\end{array}$ & $\begin{array}{l}-0.0233 \\
(0.0365)\end{array}$ \\
\hline Change in work org. & $\begin{array}{l}-0.0674^{*} \\
(0.0349)\end{array}$ & $\begin{array}{l}-0.114 * * * \\
(0.0385)\end{array}$ & $\begin{array}{l}-0.0801 * * \\
(0.0330)\end{array}$ & $\begin{array}{l}-0.0715^{* *} \\
(0.0354)\end{array}$ \\
\hline Downsizing & $\begin{array}{l}-0.137 * * * \\
(0.0329)\end{array}$ & $\begin{array}{l}-0.0913 * * \\
(0.0363)\end{array}$ & $\begin{array}{l}-0.175^{* * * *} \\
(0.0331)\end{array}$ & $\begin{array}{l}-0.173 * * * \\
(0.0355)\end{array}$ \\
\hline Controls & Yes & Yes & Yes & Yes \\
\hline Number of observations & 3,825 & 3,825 & 4,227 & 4,227 \\
\hline $\mathrm{R}^{2}$ & 0.211 & 0.166 & 0.203 & 0.215 \\
\hline
\end{tabular}

Note

(i) SURE estimates are presented, with standard errors in parentheses, *** $p<0.01$; ** $p<0.05$; ${ }^{*} p<0.1$

(ii) Pooled data from 2006 to 2012 employees aged 20-65

(iii) Controls include all variables included in Table 2, plus a dummy for whether employed at the past reference point [see note (iii) to Table 1]

included in Table 2, these effects are supplementary to any links that workplace change may have had with job characteristics and thence with well-being.

\subsection{Decomposing Changes in Well-Being}

We are now in a position to present, in Table 4, a conventional decomposition of the 2006-2012 falls in well-being into those that can be 'accounted for' by changes in the job quality variables and the workplace change variables, and those that remain unaccounted for by our observed variables. We use a simple pooled model of the 2006 and 2012 waves, with the same covariates as in Table 3.

For the Enthusiasm index we focus on males only since for females there was no significant decline to account for. Of the fall of 0.108 in the Enthusiasm index for males just over a fifth $(21 \%)$ is accounted for by the effort and participation variables combined, while another equal proportion is down to workplace change. Overall, the model accounts for $37 \%$ of the decline, and the rest can only be put down to unobserved variables.

With the Contentment index, nearly a fifth $(19 \%)$ of the 0.219 decline for males is accounted for by changing effort and participation. This share is added to by workplace 
Table 4 Decomposition of the fall in job-related well-being

\begin{tabular}{lccc}
\hline & \multicolumn{2}{c}{ Males } & \multicolumn{2}{c}{$\begin{array}{c}\text { Females } \\
\text { Contentment }\end{array}$} \\
\cline { 2 - 4 } & Enthusiasm & Contentment & $0.115^{* * * *}$ \\
\hline Fall, 2006-2012 & $0.108^{* * *}$ & $0.219^{* * *}$ & \\
'Explained' by (\% of fall) & & & $24.0^{* * *}$ \\
Effort and participation & $21.3^{* * *}$ & $18.9^{* * *}$ & $-11.9^{* * *}$ \\
Skills challenge & 11.1 & $-6.9^{* * *}$ & $11.8^{* * *}$ \\
Insecurity & 5.5 & $4.5^{* *}$ & $12.9^{* * *}$ \\
$\quad$ Workplace change & $21.2^{* * *}$ & $7.9^{* * *}$ & $36.8^{* * *}$ \\
\hline
\end{tabular}

The asterisks indicate whether the changes and 'explained' changes differ significantly from zero: $* * * p<0.01$; ** $p<0.05$; * $p<0.1$. 'Explained' differences are those associated with between-year differences in the explanatory variables (those used in Table 3 )

change and insecurity, but partly counterbalanced by an improvement in skills challenge. As a result, overall nearly a quarter $(24 \%)$ of the decline is accounted for. For females, nearly a quarter $(24 \%)$ of the smaller decline of 0.115 is accounted by effort and participation; workplace change and insecurity together add a similar amount; however, skills challenge provides a substantial counterbalance. Overall, $37 \%$ of the fall is accounted for.

Thus overall, while some of the declines in well-being are accounted for by observed workplace change and changing job quality, only a minority share is 'explained' in this way. The 'unexplained' parts of the declines can be attributable to unobserved variables with predicted high influence on well-being, about which one can speculate. One possibility is the wider forms of insecurity (fear of unfair treatment and unwanted role alteration) which are known to have risen substantially between 2000 and 2012 (Gallie et al. 2013). Another is pay cuts: with median real wages falling since 2008 , there will have been a substantial rise between 2006 and 2012 in the number of employees experiencing reductions.

\section{Conclusion}

In this paper, we have applied a model derived from several core theories of job-related well-being to a large nationally-representative sample of Britain's workers, and examined how job-related well-being changed between 2006 and 2012, that is, before and after the deepest recession to affect capitalist countries since at least the 1930s.

Our first substantive new finding is that there was a substantial fall in average jobrelated well-being over the 2006-2012 period surrounding the Great Recession, while over the same period there were some significant changes in job quality (increases in work intensity, insecurity and the pace of workplace change). For males, both Enthusiasm and Contentment fell, while for females only Contentment fell. These findings contribute to our understanding of macroeconomic and societal change, and attest to the potential benefit for national statistical offices to collect valid data and incorporate measures of well-being in their national assessments.

Tests using the model showed some new findings concerning the determinants of jobrelated well-being: 
- We found that there is only weak evidence that the marginal effect of effort on wellbeing is increasingly negative (H2); the hypothesis could only be supported in the case of the effect of work intensity on females' Contentment.

- We also report new findings concerning the effects of financial participation (where theory suggests either positive or negative effects). Our estimates implied that practices that connect organisational performance with rewards are linked with lower Contentment for males (H8, rejecting $\mathrm{H} 7)$. However, the receipt of other forms of performancerelated pay has no significant association with job-related well-being. For these other forms one can conclude, either that the effects are weak, or that opposing effects are balanced.

- We found that downsizing, work re-organisation and decreased choice are each associated directly with lower job-related well-being (H12).

- As predicted, we also found that some effects on job-related well-being differed according to the dimension of well-being. Work intensity has a more (negative) association with Contentment than with Enthusiasm (H3). Job variety and opportunities for skills use have more of a positive association with Enthusiasm than with Contentment (H9 and H10). Moreover, we find that some indicators of skills challenge (learning requirements, non-repetitiveness of tasks) are associated with higher levels of Enthusiasm but lower levels of Contentment (H9 and H10).

Our findings also confirmed results from previous studies, many of which have been obtained using non-nationally-representative data. Thus we found that task discretion has a large positive association with job-related well-being. Moreover, this link interacts with work intensity as predicted, so that, while high work intensity is associated with low jobrelated well-being (H1), task discretion is more effective at higher levels of work intensity (H5). Decision-making organisational participation is found to be associated with higher well-being (H6), the main channels being through having an influence on changes in work methods, and through the influence obtained in semi-autonomous teams. We also reconfirmed the well-established negative association between job insecurity and lower wellbeing (H11).

The model estimates accounted for a minority part of the decline between 2006 and 2012 in both dimensions of well-being. The variables that were driving this 'explained' decline were those typically associated with recession: downsizing of establishment size, rising job insecurity and work intensification not accompanied by rises in task discretion or organisational participation in decision-making. The opportunity to utilise skills increased and improved well-being slightly, and this appears to have contributed a little to the observed gender difference in declining well-being. Nevertheless, there remains a substantial part of the decline that is 'unexplained', which has to be put down to unobserved factors.

While in most instances the association of job quality variables with job-related wellbeing is the same for males and females, we draw attention to two differences of note for further research. First, while being promoted is, unsurprisingly, associated with greater Enthusiasm for males, for females there is no such effect; indeed, promotion appears to bring significantly lower Contentment. Whether this negative effect on Contentment is induced by the enhancement of job roles at a lifecourse stage when women are also bearing major domestic responsibilities deserves further examination. It may be especially relevant in the context of findings that gender gaps in job quality appear to be negligible at the start of working life, but to open out as careers develop (Manning and Swaffield 2008). Second, working in a good learning environment is positively associated with Enthusiasm, in the 
case of females; for males, however, not only is there no significant relationship with Enthusiasm, it is associated with lower Contentment. Whether this is due to different aspects of learning environments in the jobs typically done by men and women, or whether to gender-based differences in learning dispositions, also merits further investigation.

When analysing job quality and well-being, surveys of individuals (who are, after all, the job-holders and therefore best-placed informants on what happens in their jobs) are preferable to surveys of employers. Individuals are, of course, sometimes open to social esteem bias, so questionnaires have to be designed with care to minimise its occurrence. Moreover large, representative, samples taken at successive timepoints have the merits that findings are generalisable and that valid descriptions can be developed about how a nation, region or other aggregate entity is changing. While the results in this paper apply to Britain, the hypotheses are relevant everywhere. It seems quite possible that job-related well-being may have followed similar patterns in other countries experiencing the recession, even if each experience may be modified by country-specific institutions. If the data could be collected elsewhere, the same methods could be used to track and account for jobrelated well-being over time, and how this relates to macro-level events.

Nevertheless, it needs to be remembered that respondents in nationally-representative samples of workplaces will differ in many ways. Some variables may have varying meanings according to their setting, while other determining characteristics remain unobserved. This last point leads to the chief limitation of our analyses, which is that they have been conducted with successive cross-sections. One step we have taken in this paper to reduce potential endogeneity biases is to include a wide array of variables and controls, even though there are ultimate limits to how many determinants can be captured in a survey. Our most notable innovation, however, is that in the latest wave we have included controls for personality traits, the 'Big Five' measured in short form, since it could be held that these would influence the allocation to jobs as well as being strongly correlated with subjective well-being. Reassuringly, the estimated associations of our baseline model variables with well-being showed no or only small changes, when family background and personality controls were introduced. Nevertheless, given that there are likely to be other unobserved person-specific factors affecting the allocation of labour none of the estimates can be regarded as unbiased estimates. In the absence of nationally-representative panel data with equally rich job quality data, our findings summarised above should be regarded as showing consistency with the hypotheses, rather than proving causal effects.

Economic downturns are to be avoided if possible through macroeconomic management, and the effects of rising insecurity and accelerated disruptive workplace change on job-related well-being provide yet more reasons to do so. But if downturns occur it may be suggested that the control of work intensity and a better design of jobs could ameliorate some of the detrimental effects on well-being. The estimates, if taken at face value as deriving from causal effects, point to the need for more individual or team-level task discretion, greater variety (while controlling the level of required effort), more efficient use of skills, and a say in matters of work organisation. Organisational participation at a higher level, for example through better communication or a union voice, is also found to be valuable though of lesser import. By contrast, attempts to foster better performance through broadening the use of economic incentives would appear, on this evidence, to be neutral when applied at individual or team levels, but at organisational level to come at a small cost of lower well-being.

Acknowledgments The Skills and Employment Survey 2012 was funded by the ESRC/UKCES Strategic Partnership (RES-241-25-0001), with additional support from the Wales Institute of Social and Economic 
Research, Data and Methods. For the 2006 Skills Survey we acknowledge support from the Economic and Social Research Council, the Department for Education and Skills, the Department of Trade and Industry, the Learning and Skills Council, the Sector Skills Development Agency, Scottish Enterprise, Futureskills Wales, Highlands and Islands Enterprise, East Midlands Development Agency. The 2001 Skills Survey was funded by the UK Department for Education and Skills. The survey data can be accessed from the UK Data Archive (2012 data from 2014).

\section{References}

Allen, J., \& van der Velden, R. (2001). Educational mismatches versus skill mismatches: Effects on wages, job satisfaction, and on-the-job search. Oxford Economic Papers, 53(3), 434-452.

Ashenfelter, O., Doran, K., \& Schaller, B. (2010). A shred of credible evidence on the long-run elasticity of labour supply. Economica, 77(308), 637-650.

Beham, B., \& Drobnič, S. (2011). Job demands and work-home interference: Empirical evidence from service sector employees in eight European Countries. In S. Drobnič \& A. M. Guillén (Eds.), Work-life balance in Europe: The role of job quality (pp. 95-119). Palgrave Macmillan: Houndmills.

Bender, K. A., Green, C. P., \& Heywood, J. S. (2012). Piece rates and workplace injury: Does survey evidence support Adam Smith? Journal of Population Economics, 25(2), 569-590.

Bender, K. A. \& Theodossiou, I. (2013). The unintended consequences of the rat race: The detrimental effects of performance pay on health. Working Paper, Department of Economics, University of Aberdeen.

Benz, M. (2005). Not for the profit, but for the satisfaction? Evidence on worker well-being in non-profit firms. Kyklos, 58(2), 155-176.

Böckerman, P., Bryson, A., \& Ilmakunnas, P. (2012). Does high involvement management improve worker wellbeing? Journal of Economic Behavior \& Organization, 84, 660-680.

Böckerman, P., \& Ilmakunnas, P. (2012). The job satisfaction-productivity nexus: A study using matched survey and register data. Industrial and Labor Relations Review, 65(2), 244-262.

Brown, A., Charlwood, A., \& Spencer, D. A. (2012). Not all that it might seem: why job satisfaction is worth studying despite it being a poor summary measure of job quality. Work, Employment \& Society, 26(6), 1007-1018.

Bryson, A., Barth, E., \& Dale-Olsen, H. (2013). The effects of organizational change on worker well-being and the moderating role of trade unions. Industrial and Labor Relations Review, 66(4), 990-1011.

Bryson, A., \& Freeman, R. B. (2010). To join or not to join. In T. Kato (Ed.), Advances in the economic analysis of participatory \& labor-managed firms (Vol. 11, pp. 1-22). Bradford: Emerald Group Publishing Limited.

Burchell, B. (1994). 'The effects of labour market position, job insecurity and unemployment on psychological health. In D. Gallie, C. Marsh, \& C. Vogler (Eds.), Social change and the experience of unemployment (pp. 188-212). Oxford: Oxford University Press.

Cheng, G. H. L., \& Chan, D. K. S. (2008). Who suffers more from job insecurity? A meta-analytic review. Applied Psychology-an International Review-Psychologie Appliquee-Revue Internationale, 57(2), 272-303.

Cottini, E., \& Lucifora, C. (2013). Mental health and working conditions in Europe. Industrial and Labor Relations Review, 66(4), 958-988.

Datta, D. K., Guthrie, J. P., Basuil, D., \& Pandey, A. (2010). Causes and effects of employee downsizing: A review and synthesis. Journal of Management, 36, 281-348.

De Neve, J.-E., Diener, E., Tay, L. \& Xuereb, C. (2013). The objective benefits of subjective well-being. Discussion paper no. 1236, London, LSE, Centre for Economic Performance. Retrieved at http://cep. 1se.ac.uk/pubs/download/dp1236.pdf

Di Tella, R., MacCulloch, R. J., \& Oswald, A. J. (2003). The macroeconomics of happiness. Review of Economics and Statistics, 85(4), 809-827.

Dickerson, A., \& Green, F. (2009). Fears and realisations of employment insecurity. Labour Economics, 19(2), 198-210.

Eller, N. H., Netterstrom, B., Gyntelberg, F., Kristensen, T. S., Nielsen, F., Steptoe, A., \& Theorell, T. (2009). Work-related psychosocial factors and the development of ischemic heart disease a systematic review. Cardiology in Review, 17(2), 83-97.

Felstead, A., Gallie, D., \& Green, F. (2002). Work skills in Britain 1986-2001. Nottingham: DfES Publications. 
Felstead, A., Gallie, D., Green, F., \& Zhou, Y. (2007). Skills at work, 1986 to 2006. Oxford: University of Oxford, SKOPE.

Foster, A. D., \& Rosenzweig, M. R. (1994). A test for moral hazard in the labor market: Contractual arrangements, effort, and health. Review of Economics and Statistics, 74(2), 213-227.

Fox, A. (1980). The meaning of work. In G. Esland \& G. Salaman (Eds.), The politics of work and occupation (pp. 131-191). Toronto: University of Toronto Press.

Freeman, R. D., \& Kleiner, M. (2005). The last American Shoe manufactures: Decreasing productivity and increasing profits in a shift from piece rates to continuous flow production. Industrial Relations, 44(2), $307-330$.

Gallie, D. (2013). Direct participation and the quality of work. Human Relations, 66(4), 453-473.

Gallie, D., Felstead, A., Green, F., \& Inanc, H. (2013). Fear at work in Britain. London: Centre for Learning and Life Chances in Knowledge Economies and Societies, Institute of Education.

Gallie, D., Zhou, Y., Felstead, A., \& Green, F. (2012). Teamwork, skill development and employee welfare. British Journal of Industrial Relations, 50(1), 23-46.

Gosling, S. D., Rentfrow, P. J., \& Swann, W. B, Jr. (2003). A very brief measure of the Big-Five personality domains. Journal of Research in Personality, 37, 504-528.

Grebner, S., Semmer, N., \& Elfering, A. (2005). Working conditions and three types of well-being: A longitudinal study with self-report and rating data. Journal of Occupational Health Psychology, 10, $31-43$.

Green, F. (2001). It's been a hard day's night: The concentration and intensification of work in late 20th Century Britain. British Journal of Industrial Relations, 39(1), 53-80.

Green, F. (2006). Demanding work. The paradox of job quality in the affluent economy. Woodstock: Princeton University Press.

Green, F. (2008). Leeway for the loyal: A model of employee discretion. British Journal of Industrial Relations, 46(1), 1-32.

Green, F. (2009). Subjective employment insecurity around the world. Cambridge Journal of Regions, Economy and Society, 2(3), 343-363.

Green, F. (2010). Well-being, job satisfaction and labour mobility. Labour Economics, 17(6), 897-903.

Green, F. (2011). Unpacking the misery multiplier: How employability modifies the impacts of unemployment and job insecurity on life satisfaction and mental health. Journal of Health Economics, 30(2), $265-276$.

Green, F. (2012). Employee involvement, technology and evolution in job skills: A task-based analysis. Industrial and Labor Relations Review, 65(1), 35-66.

Green, F., \& Zhu, Y. (2010). Overqualification, job dissatisfaction, and increasing dispersion in the returns to graduate education. Oxford Economic Papers, 62(2), 740-763.

Greenhalgh, L., \& Rosenblatt, Z. (1984). Job insecurity: Toward conceptual clarity. Academy of Management Review, 9(3), 443-448.

Hakanen, J. J., Schaufeli, W. B., \& Ahola, K. (2008). The job demands-resources model: A three-year crosslagged study of burnout, depression, commitment, and work engagement. Work \& Stress, 22(3), 224-241.

Hamermesh, D. (1993). Labor demand. Princeton, NJ: Princeton University Press.

Kalleberg, A. L. (2011). Good jobs, bad jobs: The rise of polarized and precarious employment systems in the United States, 1970s to 2000s. New York: Russell Sage Foundation.

Kalleberg, A. L., Nesheim, T., \& Olsen, K. M. (2009). Is participation good or bad for workers? Effects of autonomy, consultation and teamwork on stress among workers in Norway. Acta Sociologica, 52(2), 99-116.

Karasek, R. (1979). Job demands, job decision latitude and mental strain: Implications for job design. Administrative Science Quarterly, 24, 285-308.

Karasek, R., \& Theorell, T. (1990). Healthy work: Stress, productivity, and the reconstruction of working life. New York: Basic Books.

Körner, T., Puch, K., \& Wingerter, C. (2011). Quality of employment. Earning money and what else counts. Wiesbaden: Statistisches Bundesamt (Federal Statistical Office).

Kornhauser, A. W. (1965). Mental health of the industrial worker: A Detroit study. New York: Wiley.

Manning, A., \& Swaffield, J. (2008). The gender gap in early-career wage growth. The Economic Journal, 118(530), 983-1024.

Mauno, S., Kinnunen, U., Makikangas, A., \& Natti, J. (2005). Psychological consequences of fixed-term employment and perceived job insecurity among health care staff. European Journal of Work and Organizational Psychology, 14(3), 209-237.

Muck, P. M., Hell, B., \& Gosling, S. D. (2007). Construct validation of a short five-factor model instrument-A self-peer study on the German adaptation of the Ten-Item Personality Inventory (TIPI-G). European Journal of Psychological Assessment, 23(3), 166-175. 
Mullarkey, S., Wall, T., Warr, P., Clegg, C., \& Stride, C. (1999). Measures of job satisfaction, mental health and job-related well-being: A benchmarking manual. Sheffield: Institute of Work Psychology.

Nolan, J. P., Wichert, I. C., \& Burchell, B. J. (2000). Workers on the edge: Job insecurity, psychological well-being and family life. Washington, DC: Economic Policy Institute.

O'Brien, G. E. (1980). The centrality of skill utilization for job design. In K. D. Duncan, M. M. Gruneberg, \& D. Wallis (Eds.), Changes in working life. Chichester: Wiley.

OECD. (2010). OECD Factbook 2010: Economic, environmental and social statistics. Paris: OECD Publishing. doi:10.1787/factbook-2010-en.

Pepper, L., Messinger, M., Weinberg, J., \& Campbell, R. (2003). Downsizing and health at the United States Department of Energy. American Journal of Industrial Medicine, 44(5), 481-491.

Roy, D. (1952). Quota restriction and goldbricking in a machine shop. American Journal of Sociology, 57(5), 427-442.

Saha, A., Tamnath, T., Chaudhuri, R., \& Saiyed, H. (2004). An accident-risk assessment study of temporary piece rated workers. Industrial Health, 42(3), 240-245.

Scott, H. K. (2004). Reconceptualizing the nature and health consequences of work-related insecurity for the new economy: The decline of workers' power in the flexibility regime. International Journal of Health Services, 34(1), 143-153.

Spencer, D. (2009). The political economy of work. Abingdon: Routledge.

Spreitzer, G., Sutcliffe, K., Dutton, J., Sonenshein, S., \& Grant, A. M. (2005). A socially embedded model of thriving at work. Organization Science, 16, 537-549.

Stephens, M, Jr. (2004). Job loss expectations, realizations and household consumption behaviour. Review of Economics and Statistics, 86(1), 253-269.

Stiglitz, J. E., Sen, A. \& Fitoussi, J.-P. (2009). Report by the commission on the measurement of economic performance and social progress. Retrieved on www.stiglitz-sen-fitoussi.fr

Tennant, R., Hiller, L., Fishwick, R., Platt, S., Joseph, S., Weich, S., Parkinson, J., et al. (2007). The Warwick-Edinburgh mental well-being scale (WEMWBS): development and UK validation. Health and quality of life outcomes, 5(1), 63.

Theodossiou, I. (1998). The effects of low-pay and unemployment on psychological well-being: A logistic regression approach. Journal of Health Economics, 17(1), 85-104.

van Wanrooy, B., Bewley, H., Bryson, A., Forth, J., Freeth, S., Stokes, L., \& Wood, S. (2013). Employment relations in the shadow of recession. Basingstoke: Palgrave Macmillan.

Warr, P. (1990a). The measurement of well-being and other aspects of mental health. Journal of Occupational Psychology, 63, 193-210.

Warr, P. (1990b). Decision latitude, job demands and employee well-being. Work and Stress, 4, $285-294$.

Warr, P. (2007). Work, happiness, and unhappiness. London: Lawrence Erlbaum Associates.

Wichert, I. (2002). Job insecurity and work intensification: the effects on health and well-being. In B. Burchell, D. Ladipo, \& F. Wilkinson (Eds.), Job insecurity and work intensification (pp. 92-111). London and New York: Routledge.

Wood, S., \& de Menezes, L. M. (2011). High involvement management, high performance work systems and wellbeing. The International Journal of Human Resource Management, 22(7), 1586-1610.

Zelenski, J. M., Murphy, S. A., \& Jenkins, D. A. (2008). The happy-productive worker thesis revisited. Journal of Happiness Studies, 9(4), 521-537. 